\title{
Power of Impeller Required for Complete Off-Bottom Suspension of Solid Particles under Gassing Conditions
}

\author{
Kazumi Satoh and Hiromi Simada*
}

Dept. of Industrial Chemistry, Science Univ. of Tokyo, Tokyo, 162

Key Words : Agitation, Power of Impeller, Complete Suspension, Three Phases, Impeller Type

The power of impeller, $\left(P_{g V}\right)_{f}$, required to attain complete off-bottom suspension of glass spheres (average diameter $72 \sim 480 \mu \mathrm{m}$, solid concentration $25 \mathrm{wt} \%$ ) was studied for five types of impeller.

It was found that the influences of gassing varied with the impeller type. $\left(P_{g V}\right)_{f}$ of axial-flow and mixed-flow impellers increased with gassing rate but that of radial flow impellers was practically independent of gassing rate. At low gassing rate the axial-flow impeller showed the lowest $\left(P_{g V}\right)_{f}$, while at high gassing rate the radial flow impeller showed lower $\left(P_{g V}\right)_{f}$ than other types of impeller. The mixedflow impeller was suitable for intermediate gassing rate.

* NGK INSULATORS Ltd.

\section{2 段翼通気擋拌槽における上・下段翼の撹拌動力 ${ }^{\dagger}$ \\ 望月雅文・武井 昇・佐藤一省 \\ 明畠高司・宮内照勝 \\ 東京理科大学工学部 工業化学科 ${ }^{\dagger \dagger}$}

多段翼通気擋拌槽は培養槽など気液接触装置として広 く用いられており，その設計には擋拌所要動力のデータ が不可欠である。しかし，単段翼の場合と異なり，通気 時の多段翼の擋拌動力を系統的に測定した報告は少なく”， その推算法屯確立しておらず2)，わずかな推算式が提出 されている゙'によよ゙まっている。てれは槽底部からガス を供給する通常の方式の多段翼擋拌槽では, 最下段翼の 近傍とそれ以外の上方の翼近傍におけるガスの分散挙動 に違いがあることに主たる原因があると考えられる。

この観点から, 本研究は幾何学的形状の異なる 2 段翼 通気擋拌槽に抢いて, 独自の新しい方法により上・下段 翼の擋拌動力を個別に測定し, それらと翼形状および操

† 1992年11月19日受理 ; 化学工学会岡山大会 (岡山, 1991 年 7 月) 扰よび化学工学会室蘭大会 (室蘭, 1992年 7 月）に て発表

†† 162 新宿区神楽坂 $1-3$
作条件との関係を実験的に検討するとともに，2段翼通 気擋拌槽の動力推算の指針を示すことを目的とした.

\section{実 験}

装置の概略をFig. 1 亿，その主な寸法をTable 1 亿示 す. 使用した擋拌槽は 4 枚邪魔板付き透明アクリル樹脂 製平底円筒槽，使用した 2 段翼は同一寸法の 2 個の 6 枚 平羽根ディスクタービンの間隔 (ディスクとディスクと の距離 $\left.h_{2}\right)$ を種々変えたものである.

擋拌動力の測定は, 翼直下の 2 本のノズルから槽液 （水道水）中に, 空気を吹き込みながら動歪みトルク計 により行った。 な抢，乙の操作はFig.1亿示すように， はじめ 1 本の回転軸に 2 個の翼を取り付け，全動力を測 定した後, 同一モーターに連結し, 中心軸の一致してい る上下 2 本の回転軸を用いることにより, 上段翼のみの 動力を测定した。また，下段翼の動力は全動力から上段 翼の動力を差し引いて算定した。なお，本方法により測 

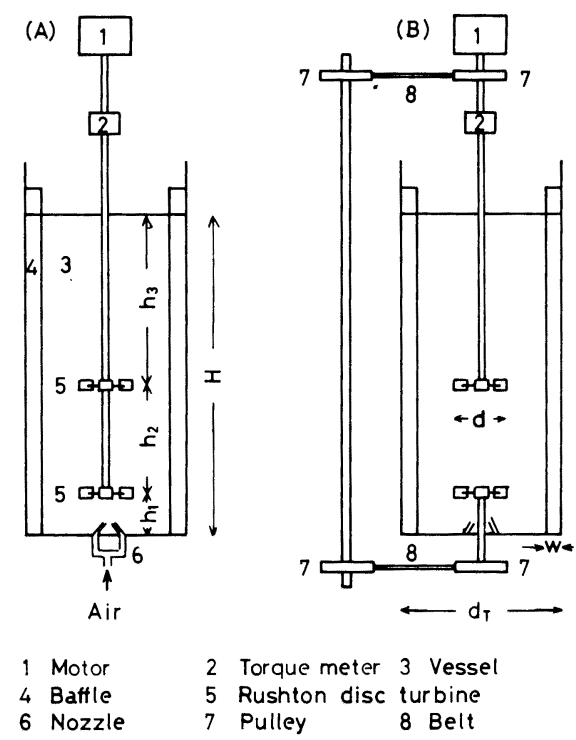

Fig.1 Experimental apparatus

定した無通気時の上・下段翼それぞれの動力は，すべて の翼間隔に扔いて测定誤差範囲内でほぼ等しかった。

\section{結果および考察}

本研究では, 主に下段翼においてフラッディングが起 きない条件 ${ }^{5)}$ のもと, 無通気時の擋拌動力 $P_{0}$, 通気時の 擋拌動力 $P_{g}$ を測定した. 特に断らない限り, 以下の結果 は上の条件下で得られたものである。

\section{1) 通気擋拌動力 $P_{g}$ と通気係数 $N_{A}$ との関係に及ぼす翼 形状の影響}

通気時之無通気時の動力比 $\left(P_{g} / P_{0}\right)$ 亿より, 同一操作 条件, 同一直径の 2 段翼之単段翼 $(H=30 \mathrm{~cm})$ を比較す ると， 2 段翼の動力比 $\left(P_{g} / P_{0}\right)_{t}$ が単段翼のそれ $\left(P_{g} / P_{0}\right)_{s}$ に比べ大きい場合 ${ }^{4)}$ 之，ほぼ等しい場合とに大別できた. さらに前者においては，上段，下段それぞれの翼におけ る動力比 $\left(P_{g} / P_{0}\right)_{U},\left(P_{g} / P_{0}\right)_{L}$ の通気係数による変化が異 なる 2 つの場合 (Figs. 2,3) か観測され, 最終的には動力 比之通気係数との関係は翼形状により, 以下に述べる 3 つの型に大別できた（Table 2) .

(1) Type I (Fig.2) $\quad d=10$ あるいは $12.5 \mathrm{~cm} の$ 翼同 士を離して配置した場合に観測された。2段翼に掞ける 無通気時を基準とした通気による動力の降下は単段翼の それに比較し小さい" ${ }^{4)}$.また, 上段翼の動力降下は下段 翼のそれに比較し，常に小さい。乙のような動力特性は, ノズルからのガスが下段翼ですべて一担翼に捕捉され， キャビティーを形成するに対し，上段翼では下段翼で分 散されたガスの一部しか捕捉しないためと推定される。

(2) Type II (Fig.3) $\quad d=10 \mathrm{~cm}$ 翼同士を比較的近ず けて配置した翼に扔いて観測された。 上段翼と下段翼の
Table 1 Experimental conditions

Vessel $d_{T}=300 \mathrm{~mm}$ number of baffles $=4$ width of baffles $=30 \mathrm{~mm}$

Dual impeller (flate six-blade disk turbine) $d=100,125,150 \mathrm{~mm}$ width of impeller blade $=d / 5$ $h_{2}=5 \sim 30 \mathrm{~mm}$ $h_{1}=75 \mathrm{~mm}$

Liquid height $H=600 \mathrm{~mm}$ Gas flow rate $Q_{g}=8.3 \times 10^{-5} \sim 7.5 \times 10^{-4} \mathrm{~m}^{3} / \mathrm{s}$ $\left(20^{\circ} \mathrm{C}, 1 \mathrm{~atm}\right)$

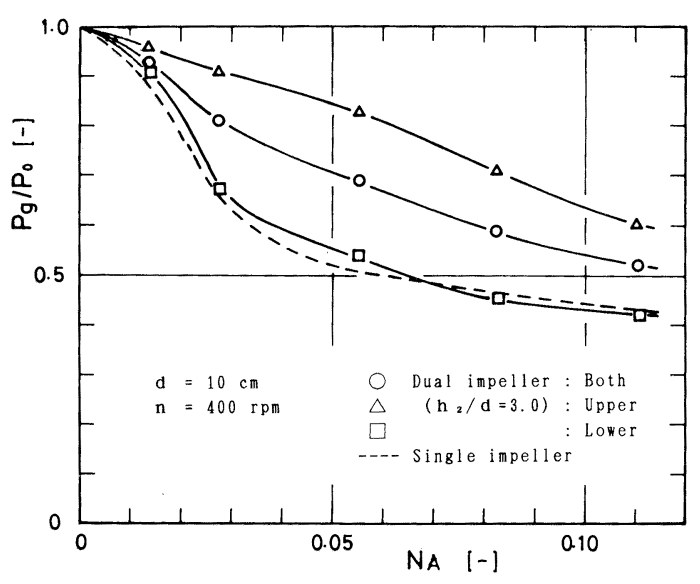

Fig.2 Power requirements for dual turbines with a large impeller spacing

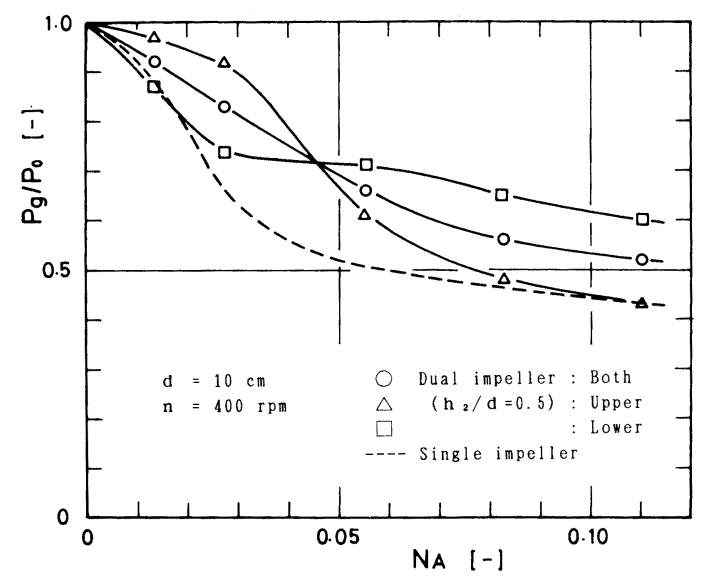

Fig. 3 Power requirements for dual turbines with a small impeller spacing

動力の大きさがガス量の増加にともない逆転する特異な 変化を呈する。乙れはガス流量が増加すると, 上段翼の 吸引作用により，下段翼に拉ける十分なガス捕捉が妨げ られるためと推定できる。 
Table 2 Relation between $P_{g} / P_{0}$ and $N_{A}\left(F_{r}>0.3\right)$

\begin{tabular}{|c|c|c|c|c|c|c|}
\hline \multirow[t]{2}{*}{$d[\mathrm{~cm}]$} & \multicolumn{6}{|c|}{$h_{2}[\mathrm{~cm}]$} \\
\hline & 5 & 10 & 15 & 20 & 25 & 30 \\
\hline 10.0 & II & II & II & I & I & I \\
\hline 12.5 & III & $\mathrm{I}$ & I & I & I & I \\
\hline 15.0 & III & III & III & III & III & III \\
\hline
\end{tabular}

Type I familiar type of Fig. 2

Type II familiar type of Fig.3

Type III $\left(P_{g} / P_{0}\right)_{L}=\left(P_{g} / P_{0}\right)_{U}$

(3) Type III（.上・下段翼の動力汭等しい） $\quad d=12.5$ $\mathrm{cm}$ の翼間隔 $5 \mathrm{~cm}$ 执よび $d=15 \mathrm{~cm}$ の翼に拈いて観測さ れた。乙の現象は翼同士が接近している場合には, 翼幅 の広い単段翼のようなガス分散挙動を示すためである。 一方, 翼間隔が広い場合には，上・下段翼それぞれが独 立してガス分散に寄与しており Type I の関系が予測さ れたが，槽壁と翼との間隙が狭いため上段翼におけるガ スの捕捉が容易になり, 見掛けの通気量が増加するため と考えられる.

2) 単段翼 $\boldsymbol{P}_{\boldsymbol{g}, s}$ と下段翼における動力 $\boldsymbol{P}_{\boldsymbol{g}, L}$

Table 2 中のI, III印の形状の翼において, 下段翼の動 力は, Fig.2 から明らかなように, 同一操作条件下の単 段翼のそれと同じであった。この結果，「キャビティー を形成し，ガスを十分捕捉・分散している下段翼の動力 はガス分散挙動汃似通っていることから, 同一操作条件 の単段翼の動力と同じとできる」とした従来の推論の妥 当性を実験的に確かめた。 てれについてはHudcova ら あ同様の結果を報告しているが, 本研究ではより多くの 形状の翼においても, 従来の推論が正しいてとを立証し た.

なお，翼間の相互作用が強い翼 (Table 2 II 印) あるい はフラッディング状態にある場合には, 下段翼の動力は 単段翼のそれより大きい。

3) 上段翼の動力 $\boldsymbol{P}_{g, U}$

本研究で用いたすべての翼において, 上段翼の動力降 下はガスホールドアップ $\left(N_{A}=0.1, \phi<0.1\right)$ に対応する 見掛け密度の低下によるもの以上に降下しており，上段 翼に掞いてもかなりの量のガスが捕捉されていると考え られた ${ }^{6)}$. 事実, ストロボ・フラッシュを用いた目視観 察によると, 上段翼においても下段翼同様キャビティー が形成されていた。乙の結果, 下段翼において分散され たガスが気液混相流として上段翼近傍に流入し, 上段翼 にガスが捕捉・再分散されるためと考察できた。

Fig. 4 亿直径の異なる翼における上段翼の動力比を示 す. $d=10 \mathrm{~cm}$ の翼では, 上段翼の動力が単段翼のそれに

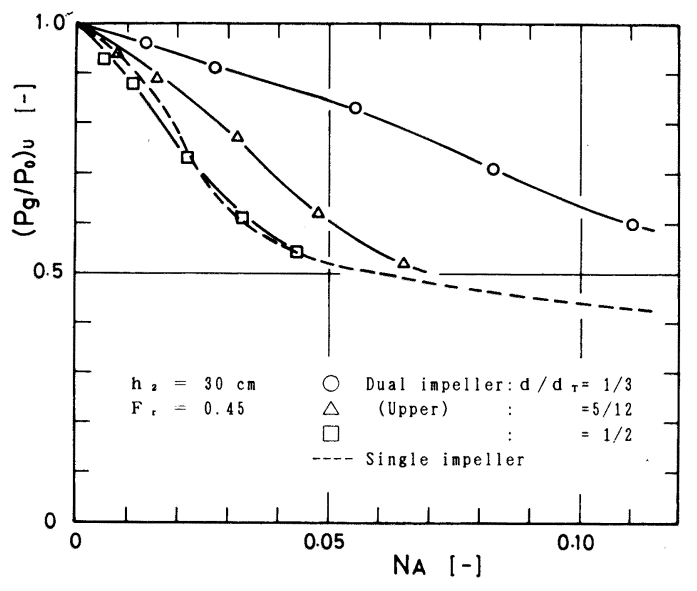

Fig. 4 Effects of diameter ratio of impeller to vessel $d / d_{T}$ on power requirements at $F_{r}=0.45$

比較し大きいが，翼径の増加とともに単段翼に近づき， $d=15 \mathrm{~cm}$ の翼では単段翼と同じになる．乙れは前述の ように, 翼径が大きくなると, 槽壁と翼との間隙が狭く なり，上段翼に拈けるガス捕捉量が単段翼あるいは下段 翼と同程度に増加するためである。

\section{結 言}

種々の形状を持つ 2 段翼において，独自の新しい方法 により上・下段翼の通気擋拌動力を個別に測定し, 以下 のととを明らかにした。

1）ガスを十分捕捉・分散している下段翼の動力は同 一操作条件下の単段翼のそれと同じといえた.

2）通気による上段翼の動力降下はガスホールドアッ プによる見掛け密度の減少によるものより著しく大きか った。 また, 上段翼におけるガス捕捉量が上段翼の動力 を支配していると推定できた。

3）翼径と槽径の比が大きい場合には，上段翼の動力 あまた同一操作条件の単段翼の動力と同じになった.

[ 謝 辞 ] 本研究の実験, 解析に協力戴いた早川奈世子, 铇田小百合の両氏に感謝の意を表します.

\section{Nomenclature}

$d=$ diameter of impeller

[m]

$d_{T}=$ diameter of vessel

[m]

$F_{r}=$ Froude number $\left(=n d^{2} / \mathrm{g}\right)$

$h_{2}=$ impeller spacing

$N_{A}=$ gas flow number $\left(=Q_{g} / n d^{3}\right)$

$n=$ rotation speed of impeller

$P=$ agitation power input

$Q_{g}=$ gas flow rate $\left[\mathrm{m}^{3} / \mathrm{s}\right]$ 
$<$ Subscripts $>$

0 = unaerated

$g=$ aerated

$L=$ lower impeller

$t=$ total (dual impeller)

$s=$ single impeller

$U=$ upper impeller

\section{Literature cited}

1) Fukuda, H., Y. Sumino and T. Kanzaki: Hakkokougakukaishi, 46, 838-845 (1968)
2) Hudcova, V., V. Machon and A.W. Nienow: Biotech. Bioeng., 34, 617-628 (1989)

3) Machon, V. and J. Vicek: Collection Czechoslovak Chem. Commun., 50, 2863-2872 (1985)

4) Nienow, A.W. and M.D. Lilly: Biotech. Bioeng., 21, 2341-2345 (1979)

5) Smith, J.M., M.M.C.G.Warmoeskerken and E.Zeef: C.S. Ho and J.Y. Oldshue ed. "Biotechnology Processes : Scaleup and Mixing”, p. 107-115, AIChE (1987)

6) van't Riet, K, J.M. Boom and J.M. Smith: Trans. Inst. Chem. Eng., 54, 124-131 (1976)

\title{
Power Required for Upper and Lower Impellers in Gas-Liquid Stirred Vessels with a Dual Turbine
}

\author{
Masafumi Mochizuki, Noboru Takei, Kazumi Satoh, \\ Takashi Akehata and Terukatsu Miyauchi
}

Dept. of Industrial Chemistry, Science Univ. of Tokyo, Tokyo 162

Key Words : Power Requirement, Dual Impeller, Aerated Vessel, New Measurement Method, Impeller Diameter

Values of aerated power required at upper and lower stages of a dual impeller under loading state in stirred vessels were measured with a unique method. The following points: were revealed.

1) The power of the lower stage in most dual impellers and the power of the upper stage for the impeller of largest diameter in this work were equal to that of a single impeller operating in the same condition. 2) The power of the upper stage was smaller than that expected for an unaerated impeller in a fluid of density equal to that of the gas-liquid mixture. 